\title{
EEN WESTINDISCHE GOUVERNEUR UIT DE 18de EEUW
}

DOOR

\section{S. KALFF}

In vergelijking van de koloniale letterkunde betreffende Oostindië bezit die over Westindië slechts weinig werken, welke op ééne lijn te stellen zijn met die van Valentijn, Junghuhn, Veth, v. Rhede v. d. Kloot en zoovele anderen. Dit geldt mede van het biografisch element; van de Surinaamsche gouverneurs b.v. bestaan slechts weinige monografiën, welke het gemis van systematische levensgeschiedenissen eenigermate doen vergeten.

Intusschen zijn enkele mannen van beteekenis in geschrifte eervol herdacht geworden, en in het kader van hun tijd, tegen eene Westindische samenleving als achtergrond geplaatst, brengen deze portretten als 't ware eene periode van de koloniale geschiedenis met zich. Hunne lotgevallen zijn nauw verbonden met die van het wingewest, 't welk zij bestuurden, terwijl het relaas daarvan een blik vergunt op eene koloniale maatschappij evenzeer onder de tropen levend als de Oostindische, en toch ver daarvan afwijkend.

Over de levens van de gouverneurs der Westindische Comp. Joan Maurits van Nassau-Siegen, gezegd de Braziliaan, en Cornelis Aerssen van Sommelsdijk zijn de bronnen tamelijk overvloedig, en bekend is v. Sypesteyn's levensschets van den gouverneur JanJacob Mauricius. Ook over een zijner opvolgers, Jan Nepveu, zijn de gegevens, ofschoon verstrooid, geenszins zeldzaam, en de toekomstige levensbeschrijver heeft het voordeel dat hij ten aanzien van deze figuur putten kan uit het journaal, door 
hem te boek gesteld ${ }^{1}$ ). Zulk een levensschets mag alsdan eene plaats bekomen dicht bij die van Mauricius, want beide waren tijdgenooten en geestverwanten, beide mannen met ongewone gaven welke zij, zooveel als zij tegen den stroom konden oproeien, ten bate der kolonie aanwendden.

Nepveu stamde uit een geslacht van Fransche refugiés; zijne grootouders, Aubin Nepveu en Anne Baron, waren bij de opheffing van het Edict van Nantes naar Nederland uitgeweken. Hij werd op 27 Aug. 1719 te Amsterdam geboren uit het huwelijk van Louis Nepveu en Suzanne Hamelot; hij ontving eene goede opvoeding te Weesp en in zijn geboortestad. Toen hij in 1734 naar Suriname vertrok waren zijne ouders daar reeds gevestigd; hij maakte er sneller carrière dan hem in Nederland waarschijnlijk mogelijk zou zijn geweest. Zijn staat van dienst luidde dat hij in 1740 het ambt van gezworen klerk te Paramaribo vervulde, en twee jaren daarna als secretaris van den gouverneur Mauricius optrad; in 1745 provisioneel, en in 1751 effectief secretaris van het Hof van Policie werd, vervolgens, drie jaren later, tweede raad fiskaal, in 1761 eerste raad fiskaal, in 1768 gouverneur ad interim, welke post hij ook reeds te voren had waargenomen. Eindelijk werd hij in 1770, bij het aftreden van den gouverneur Wigbold Crommelin, door directeuren van de Societeit van Suriname aangesteld tot diens opvolger met de titels van gouverneur-generaal, kolonel der militie en president van alle hooge colleges. De voordeelen, aan dezen hoogen post verbonden, bestonden uit een jaarlijksch inkomen van $f 9000$ de emolumenten der Secretarie, vijf procent van de Westindische staatsschuld, den handel der Indiaansche lijfeigenen alias slaven, het gebruik van het gouvernementshuis met tuin, en kostelooze bediening door landsslaven.

1) Over "De Annotatien van Gouverneur Jan Nepveu op Herlein's Beschrijving van Suriname", zie De West-Indische Gids, 2e jg.(October 1920 blz. $311 \mathrm{vlg}$.

In de ,Verslagen omtrent 's Rijks oude archieven." XLI, eerste deel, 1918, Bijlage XV, 's Gravenhage 1919 geeft Dr. J. de Hullu een beschrijving van de "Stukken, afkomstig van Jan Nepveu”, in het Algemeen Rijksarchief aanwezig. 
Zoo waren althans de voorwaarden onder Mauricius, wiens secretaris hij was geweest; en ze waren dezen hoog genoeg aangerekend door zijne vijanden in Nederland. Maar dat deze inkomsten niet zoo bijster voordeelig waren, bleek wel uit diens verantwoording aan directeuren der Societeit. Het salaris toch was onderworpen aan eene aanzienlijke korting en de Secretarie bracht, behalve voordeelen, ook uitgaven met zich. Beide factoren wogen tegen elkaar op. De procentage van de W. I. Schuld bracht gemiddeld $f 342$ 's jaars op - „,ce n'était pas le Pérou! Nog minder voordeel zat er aan den slavenhandel vast; die in Indiaansche lijfeigenen beteekende zooveel minder dan de handel in negerslaven. Maar 't was kenschetsend voor den geest des tijds dat in de tweede helft van de 18de eeuw een gouverneur van Suriname een gedeelte van zijn inkomen moest vinden in.... menschenhandel.

Het bewonen van een ruim en geriefelijk woonhuis was inderdaad voor de gouverneurs een voordeel, ofschoon de tuin uit louter schelpzand bestond en veel onderhoud vereischte. Evenzoo het huis zelf, en daarvoor viel op de huisslaven niet te rekenen. 't Waren geen arbeidskrachten gelijk in het vaderland, maar lieden die geplaagd waren "met de kwale pigritia, op syn duyts luyigheyd genaamt." Overigens konden de inkomsten, aan het ambt verbonden, den familievader geenszins onverschillig zijn, want Nepveu was gehuwd man met een tamelijk groot huishouden. Zijn eerste vrouw was Johanna Agatha Ouderogge, die hem vijf kinderen schonk; na haar overlijden hertrouwde hij met Elisabeth Buys, weduwe van Isaak Stolkert, welk huwelijk kinderloos bleef.

Het gouvernementshuis verschilde, behalve door de afmetingen en de inrichting, ook hierin van de overige gebouwen te Paramaribo, dat het van gebakken steen was opgetrokken; alle andere van hout. Alleen de woning van den kommandant der krijgsmacht was evenzoo van steen, dochwerd door een brand verwoest. Overigens warendehuizen der notabelen kostbaar genoeg ingericht; kapt. Stedman schreef in zijne Reize etc. dat ze waren ,met schilderyen, verguldzelen, krystallen kroonen, porcelein en dier- 
gelijke rijk opgesierd, de kamers noch behangen, noch gepleisterd, maar met ceder-, brazilië- en mahagonyhout zeer fraai beschoten." Nepveu moest wel een man in bonis zijn dat hij zulk een huis voor zich kon laten bouwen 't welk hem, volgens denzelfden schrijver, op $f 150.000$ te staan kwam.

Door een dertigjarigen diensttijd in de kolonie, alvorens hij tot het gouverneurs-ambt geroepen werd, was hij vertrouwd met hare nooden en behoeften, met de samenleving en de sociale toestanden in Suriname; hij kende land en volk. Maar tevens was hij van nabij betrokken geweest in de hevige geschillen, die onder het bestuur van Mauricius zooveel verdeeldheid in 't land brachten, en eindigden met de schorsing en terugroeping van dien gouverneur. De kleine maatschappij in Suriname was toen verdeeld in twee vijandelijke kampen: voor of tegen Mauricius. De christelijke bestuurder der kolonie schreef bedeen vastendagen uit, de coloniers vierden die dagen met spel en drank. De gouverneur ijverde tegen slavenmishandeling, de colonier voor het recht om zijn gekocht en betaald eigendom als vee te beschouwen. De gouverneur bedreigde met strenge straffen het losbandig krijgsvolk; het krijgsvolk gaf te verstaan dat de geweren nog niet verroest waren, waarmee men den gouverneur v. Sommelsdijk had neergeschoten. Van de dingen, welke boven de grove materieele genoegens des levens stonden, was geen sprake; kunst was er onbestaanbaar, en de vreugde aardde naar varkensvreugde. Mauricius had eene machtige planterspartij tegen zich, en aan het hoofd van die vijandige factie, door hem La Cabale genoemd, stond het lid van den Raad van Policie Salomon Duplessis, die hem eerlang bij directeuren in 't vaderland in staat van beschuldiging zou stellen. Deze Cabale, waaraan ook het vrouwelijk element ijverig deelnam, was iets meer dan eene tijdelijke coalitie van ontevredenen; zij vormde eene georganiseerde en permanente commissie. Er was een voorzitter en een penningmeester; ook een secretaris, Jean Paul Taunay genaamd, die als la meilleure plume van de partij belast was met het voeren der correspon- 
dentie, het opstellen der bezwaarschriften aan directeuren der Societeit van Suriname, enz. Hij werd door den gouverneur als ",pensionaris der Cabale" aangeduid; een ander notabel lid, Dirk Guldensteede, als „Dirkje Speelop", en zekere mevr. Audra, de werkzaamste vrouwelijke factor, als ,'t saligh oudwijf."

Aldeze krakeelen, al deze intrigues had Nepveu meegemaakt, en te samen met zijne broeders Aubin en Louis Pierre behoorde hij tot de ijverigste leden van de partij des gouverneurs . Deze, van zijn kant, stelde in zijn voormaligen secretaris een vol vertrouwen; hij gaf hem ook grooten lof ter zake van zijne eerlijkheid en bekwaamheid. Mauricius was meer dan eens in de bres gesprongen voor de belangen der familie Nepveu. Aldus bij gelegenheid dat een harer leden, de procureur Nepveu, bij eene societeitsruzie met een lid van den Raad van Policie, dezen had toegeduwd: ,de raden van policie zijn geen goden op aarde!' Daarvoor was hij door den ander aangeklaagd, en het Hof van Policie, meerendeels uit ongestudeerde en onbevoegde personen bestaande, had hem veroordeeld om met een gloeienden priem door de tong te worden geboord. Dit buitensporig vonnis werd uitgesproken op grond van "godslastering”; er was bij de beleediging immers iets gezegd over ,goden op aarde." Mauricius had echter niet te vergeefs in de rechten gestudeerd; hij vernietigde aanstonds deze "ridicule sententie”. Doch zijn eigen zaak vermocht hij niet te redden, en 't was met leedwezen dat de gebroeders Nepveu hem de gedwongen reis naar het vaderland zagen aanvaarden.

$\mathrm{Na}$ hem kwam de generaal-majoor von Spörche aan het bewind, als eerste van de uit Nederland gezondene commissarissen; na dezen de gouverneurs Wigbold Crommelin (ad interim) en Pieter Albert van der Meer, totdat in 1756 de beurt aan Jan Nepveu kwam. Evenwel slechts tijdelijk; nog geen half jaar voerde hij het bestuur, 't welk hij in 1757 overgaf aan Wigbold Crommelin. Deze vertrok in 1768 met verlof naar Nederland, en vroeg daar zijn ontslag. Ruim een jaar trad Nepveu op als waarnemend gouverneur, totdat op 5 Febr. 1770 zijne defini- 
tieve aanstelling volgde. Reeds aan den vooravond van zijne installatie ondervond hij de aanvechting van tegenstanders, mannelijke en vrouwelijke. De invloed van deze laatsten was van ouds eene verborgen, maar krachtige strooming in het openbare leven geweest, reeds vóór dat het huis van mevr. Audra tot zetel van La Cabale diende. Nepveu had bij zijn optreden eveneens rekening te houden met vrouwelijke tegenkanting. In zijn journaal teekende hij op dat de echtgenoote van zijn voorganger Crom melin het gouverneurshuis niet voor hem wilde inruimen, dat zij de feestelijkheden bij zijne installatie bemoeilijkte door eenige noodwendigheden daarvoor te weigeren, dat zij tegen hem intrigueerde, enz.

In weerwil van die strubbelingen had het feest bij zijne bestuursaanvaarding een goeden afloop. Bij den galamaaltijd zaten bijna alle notabelen in de kolonie aan, terwijl voor de joodsche regenten wegens de ritueele eischen van hun godsdienst een afzonderlijke disch was aangerecht. In een groote, feestelijke versierde loods buiten het gouverneurshuis werden de ambtenaren en geëmployeerden van minderen rang, zoomede het personeel van de schepen ter reede onthaald. Illuminatie en vuurwerk, bal en receptie behoorden tot het programma van die feestdagen; de officieren van het oorlogsschip Castor betuigden bij die gelegenheid dat ,de optooysels naar de smaak en de kostelijkheid van kleeding en juweelen" hunne verwachting verre overtroffen. Na afloop van het feest te Paramaribo werd de nieuwe gouverneur gehuldigd op de joode Savane, tien uren roeiens van de hoofdplaats, waarmee weder tal van ceremoniën en feestelijkheden gepaard gingen.

Er heerschte toen uiterlijk veel welvaart, althans veel prachtvertoon in de kolonie. De stad Paramaribo werd telken jare uitgelegd; het aantal huizen, door Stedman op gegeven met ongeveer1400, vermeerderde zich steeds. Evenzoo het aantal paarden en rijtuigen, en op de plantages werden kostbare gebouwen opgericht. De Fransche gouverneur van het eiland Martinique, d'Ennery, die in 1769 met een gevolg van 24 officieren Suriname bezocht, 
verwonderde zich over ,,de extra-groote rëe met kostelijke schepen, de heerlijke gebouwen op de plantaadjes." En toch was de aanvaarding van Nepveu's bestuur eene „bekommerlijke successie", toch was dit uitwendige voorkomen van de kolonie slechts een blinkende sluier geworpen over een door sociale euvels ondermijnd staatslichaam. De geschiedschrijver getuigde daarvan:

„De achteruitgang van Suriname was niet tegen te houden. Er rustte geen zegen op het door afpersing van arme slaven verworven geld. Het werd roekeloos verspild en Suriname's ingezetenen stapelden dwaasheden op ongeregtigheden, en ongeregtigheden op dwaasheden, en bereidden alzoo zelve den ondergang voor. En ofschoon Nepveu een bekwaam en door ondervinding geleerd man was, kon hij echter den stroom van onspoed niet tegenhouden, waarin zoovele kapitalen werden verzwolgen. Had het in zijne magt gestaan, hij had dit gedaan, want het ontbrak hem bij goeden wil en energie ook niet aan de noodige kennis der kolonie. Trouw en eerlijk in zijn handel en wandel had hij niet slechts zich de achting en het vertrouwen der Societeit verworven, ook door andere belanghebbenden (de geldschieters) werden zijne verdiensten erkend en zelfs was de oppositie, vroeger zoo lëvendig, tegen hem verminderd. Hoewel hij in belangrijke zaken pal stond, gaf hij in kleinigheden waar hij dit vermogt toe, en daardoor werd mede de verhouding tusschen Nepveu en de kolonisten van vriendschappelijker aard dan zij bij Mauricius en Crommelin geweest was. ${ }^{\mathbf{1}}$ ).

Er waren inderdaad tal van oorzaken, die onder het bestuur van Nepveu de kolonie in het achterschip hielpen: het lichtvaardig gebruik van de in Nederland verstrekte credieten, de woekerpraktijken der geldschieters, de verkwistingen der planters, de drukkende belastingen, het verval der plantages, de kosten der militaire maatregelen, 't een met het ander veroorzaakte eene financieele crisis. Binnen een betrekkelijk korten tijd was de kolonie beladen met een schuld van 50 millioen aan Hollandsche

1) Wolbers, Gesch. v. Suriname, p. 300. 
handelshuizen. De achteruitgang was zoo merkbaar, dat in een adres van zesendertig. inwoners van Paramaribo aan den gouverneur en den kolonialen raad de vrees werd uitgesproken ,dat aan alle ingezetenen der kolonie zal worden vervuld de vloek der joden: oud en arm te zijn," Nog in 1779, zijn sterfjaar, teekende Nepveu in zijn journaal aan: „Er heerscht hier tegenwoordig zoo groote armoede dat veele blanken, die men 't niet aan zoude sien, sig met een drooge bananne moeten behelpen."

De gevolgen der verdoemelijke slavernij droegen er toe bij den toestand hachelijk te maken. In 1772 brak een slavenopstand uit in het oostelijk gedeelte der kolonie, over de Cottica rivier, en 't was waarlijk de eerste maal niet. Als een der voornaamste oorzaken van die herhaalde neger-oproeren noemt de geschiedschrijver v. Kampen de mishandeling der slaven en de corruptie der planters", die hunne zwarten niet alleen tegen de wetten der menschelijkheid, maar ook tegen die van het blijkbaarste eigenbelang, en erger dan lastdieren behandelden. Men bedacht niet dat 125 plantaadjen der volkplanting, die door elkander elk op 180 slaven berekend werden, 76.500 dier ongelukkigen konden bevatten, welke door het voorbeeld der vrije Seramica- en Ouka-negers ligtelijk tot navolging (van deserteeren) konden worden bewogen." Bij den opstand in Berbice van 1763 spaarden de negers bij den moord der blanken en hunne gezinnen alleen den predikant, uit overweging dat hij de man was die met God sprak en voor hen bad. Men stelde hem in vrijheid met de opdracht dat hij den gouverneur kon gaan zeggen, ,dat de wreede behandeling door eenige bij name aangeduide planters de oorzaak was van dezen opstand." Evenals in Berbice vluchtten ook in het Cottica-distrikt de bedreigde Europeanen met hunne gezinnen naar de hoofdplaats, waar ze onder de kanonnen van het fort Zeelandia veilig waren. Ook Mauricius had in zijne brieven naar 't vaderland herhaaldelijk die wonde plek van de slavernij aangeraakt, en gewaagd van den Augias-stal, dien hij in deze kolonie te keeren had. Doch de bezem van het gezag, welke hem daarvoor ten dienste stond, reikte niet; zoo 
min als dat bij Nepveu het geval was. In zijn Rijmbrief aan Willem van Haren had Mauricius stof gevonden voor de regels:

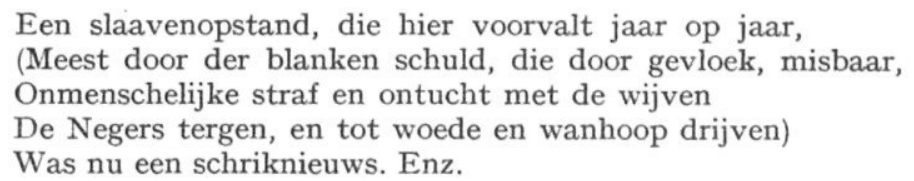

Gelijk zijne voorgangers was Nepveu de voorzitter van het Hof van Policie en Crimineele Justitie, evenals van het Hof van Civiele Justitie, doch tegen een zoo diepgaand en zoo verouderd euvel als de slavernij was hij niet opgewassen. Hij bezat daartoe ook niet de macht, en vond bij het Hof van Policie geen steun. Want de leden daarvan, gekozen uit de aanzienlijkste ingezetenen en onbezoldigd, waren zelve de voornaamste plantage eigenaren en dienden meer de particuliere belangen van het gild dan de openbare van de kolonie. De gouverneurs waren zelve slavenhouders; Mauricius had plantages gekocht voor zijne zoons, Nepveu bezat voor 't minst eene steenbakkerij Appe-kappe genaamd, die hem volgens de opgave bij Stedman veel opbracht. En voor de werkzaamheden op zulke ondernemingen waren onvermijdelijk slaven noodig; de dagen van den invoer van vrije koelies waren toen nog verre. Hadden de Christenen van die tijden eene christelijke rechtspraak gehad, en den neger minder als ploegvee beschouwd, het zwarte gevaar zou niet zoo groot zijn geweest. Doch nu ze voor den zwaarsten veldarbeid gebezigd werden, aan de zwaarste straffen onderworpen, en gestadig de zweep van den bastiaan voor oogen hadden, deserteerden de negers bij tientallen. En daar de wildernis geen voedsel opleverde, overvielen zij de afgelegen plantages om er te plunderen en te blakeren.

Zoo was de toestand geweest onder Mauricius, zoo bleef die onder zijne opvolgers. Behalve met deze Marrons of weggeloopen slaven had men rekening te houden met de strooptochten der Boschnegers, welke zich somtijds tot onder den rook van Paramaribo waagden. Er moesten, nadat in 1772 verscheidene plantages geplun- 


\section{EEN WESTINDISCHE GOUVERNEUR UIT DE 18DE EEUW}

derd of verbrand waren, buitengewone maatregelen genomen worden, en tegelijk dat Nepveu de uitzending eener militaire macht in 't vaderland aanvroeg, richtte hij in de kolonie zelve een paar vrijkorpsen op. 't Eene bestond uit twee kompagniën ter gezamenlijke sterkte van 125 tot 150 man. Het werd in 1770 gerekruteerd uit vrijverklaarde negers; als bijdrage tot hun onderhoud werden hun eenige kostgronden in den omtrek der hoofd-, plaats aangewezen. Men noemde dezen troep het Korps Vrijnegers of 's Lands Vrijkorps. Ongeveer twee jaren daarna werden 300 koppen uit de beste en sterkste plantageslaven gekozen en tot hooge prijzen van de eigenaars aangekocht. De regeering betaalde toen $f 800$ voor een slaaf als minimum; voor enkele bekwame handwerkslieden onder hen werden zelfs prijzen tot $f 3400$ besteed. $\mathrm{Zij}$ werden allen vrijverklaard en onder een uit hun midden gekozen kader geplaatst, terwijl de officierdienst verricht werd door 3 à 4 blanke ,conducteurs”, met den rang van vaandrig. Het bevel over dit korps jagers werd somtijds opgedragen aan een kapitein van het garnizoen, zooals de kapitein luitenant Frederici, en na hem de kapitein Stielman. Aan hunne monteering werd niet veel ten koste gelegd, ze bestond slechts uit een broek en een groene muts met het volgnummer van hun korps, terwijl ze bewapend waren met geweer en sabel; de scherpschutters onder hen met een buks. Toen later eenige van die groene mutsen in handen van de Boschnegers waren geraakt, werden voor het korps scharlaken mutsen ingevoerd. Van daar dat men deze zwarte militairen in de wandeling redi moesoe of roodmutsen noemde. Het korps jagers werd beschouwd als superieur boven de Vrijnegers, en het gold als eene onderscheiding daarbij te dienen. In de oorlogen tegen de Marrons en Boschnegers bewees het uitstekende diensten; na de beëindiging van die oorlogen bleef het voortbestaan onder den naam van Koloniale Guides.

In $1773 \mathrm{kwamen}$ de gevraagde suppletietroepen uit het vaderland, 800 man onder het kommando van den kolonel Louis Henry Fourgeoud, een Zwitser van geboorte. 
Deze was geen nieuweling in de kolonie; hij had zich reeds verdienstelijk gemaakt bij het dempen van den slavenopstand in Berbice, in 1763, en stond in aanzien bij den prins-stadhouder (Willem V). Ofschoon zijn oploopend en heerschzuchtig karakter hem vele vijanden bezorgde, werden zijne krijgsmansdeugden, inzonderheid zijn moed en volharding, ook door deze erkend. Doch tusschen hem en den gouverneur ontstond welhaast eene verwijdering, die tot vijandschap oversloeg. Het moest bij Nepveu wel eenigen naijver wekken dat de prins aan dezen kommandant het bevel had opgedragen niet alleen over de hulptroepen, maar ook over de geheele krijgsmacht in de kolonie. Hij beschouwde dit als een inbreuk op de waardigheid van kolonel der militie, hem bij zijne aanstelling verleend. Het verschil in beider karakter vergrootte de spanning. De schrijver van de ,Reize in de binnenlanden van Suriname", J. G. Stedman, die als kapitein bij dit hulpkorps was ingedeeld, vermeldt dat Fourgeoud al dadelijk bij de ontscheping der troepen aanleiding tot kritiek gaf door ze met den rug naar het paleis van den gouverneur op te stellen. Er vormden zich onder de ingezetenen twee partijen, waarvan de eene Fourgeoud als de redder der kolonie beschouwde, terwijl de andere volhield, dat hij en zijn volk die kolonie slechts tot last waren, en de reeds zoo zware militaire uitgaven noodeloos vermeerderden. De zwarte vrijkorpsen waren, zoo men meende, voldoende voor de openbare veiligheid. „De notulen van den kolonialen raad, vooral het journaal van Nepveu, bevatten tal van bijzonderheden omtrent de strubbelingen en misverstanden, door de komst der troepen in de wereld gebracht. Ook over het verschil van inzicht tusschen de machthebbers, b.v. over den eisch van Fourgeoud om de troepen naar de buitenposten te zenden", alsoo se aan Paramaribo door debauches vrij meer onbequaam en buyten staat raakten, klaagende dat se genoegsaam alle aan Venus-siekte laboreerden.'

De gouverneur wenschte den uitslag van zijne onderhandelingen met de Boschnegers af te wachten, de kommandant daarentegen wilde onverwijld tegen hen opruk- 
ken en dreigde dat, zoo men hem niet noodig had, hij zijn volk weer zou inschepen. Daarvoor maakte hij ook tot tweemaal toe aanstalten, doch de vertoogen van den Raad en berichten over nieuwe aanvallen op de plantages kwamen telkens in den weg. Eindelijk bracht eene nederlaag, door de Marrons aan de troepen der Societeit toe gebracht, het zwaard uit de scheede. Een guerilla-oorlog in de bosschen ving aan, waaraan door de geheele koloniale krijgsmacht, ongeveer 2300 man, werd deelgenomen. Die campagne kenmerkte zich door vele langdurige en bezwaarlijke tochten in de wildernis, door vernieling van negerkampen en kostgronden, overrompelingen van plantages door den vijand, vruchtelooze boschpatrouilles en van weerskanten gepleegde gruwelen. De verschillende episoden van die guerilla, welke met afwisselend geluk gevoerd werd, vonden hun kroniekschrijver in kapt. Stedman, die hier als ooggetuige optrad. Nepveu had reden voldaan te zijn over de door hem opgerichte negerkorpsen want deze toonden zich zooveel meer gehard, tegen vermoeienissen en ontberingen bestand, bruikbaar in een tropisch klimaat, dan de uit Nederland gekomen militairen.

Toch was de zg. kleine oorlog in de haast ondoordringbare wildernissen van het binnenland een moordend ondernemen, ook voor de Vrijnegers en de zwarte jagers. Het gevaar voor de afgelegen plantages kwam niet van de inheemsche Indianenstammen, de Karaïben, Arrowaks en Warauns, maar van de weggeloopen plantageslaven, die aan de zweep der Surinaamsche Legree's ontvlucht waren. Voorts van de Bosch- en Condie-negers, die reeds onder de eerste gouverneurs een gevaar voor de kolonie waren geweest. In de moerassige wouden van het zuidelijke binnenland hadden zij hunne gehuchten gebouwd, ware roofnesten achter eene natuurlijke defensielijn van moerassen, doorn- en stekelplanten. Tijdens den inval van den Franschen admiraal Cassard, die de jonge kolonie had geplunderd en gebrandschat, hadden vele plantage-eigenaars hunne slaven de bosschen ingezonden, opdat zij niet den buit der indringers zouden wor- 
den. Doch nadat die vijand was afgetrokken, viel het den planters niet licht om hun eigendom weer in handen te krijgen. De slaven keerden uit de wildernis niet terug; of, zoo al, dan was het gezamenlijk en gewapend, in benden van stroopende outlaws. Hunne rooftochten tegen de plantages werden beantwoord met de uitzending van vliegende kolonnes, zg. kommando's, maar die gemeenlijk weinig uitwerkten. De afstand van de kust tot de ruwe versterkingen des vijands bedroeg vaak niet minder dan zeventien dagreizen, de moerassen waren ondoorwaadbaar, de wouden dompig en koortswekkend, zonder voor den Europeaan iets eetbaars op te leveren. De mondbehoeften zoomede de krijgsvoorraden konden enkel meegevoerd worden op de harde koppen van negerslaven, die niet zelden de kans waarnamen om zich te verwijderen, d. i. om zich bij hunne vrije stamgenooten te voegen. Daarbij kwamen de aanvallen van een in hinderlaag opgestelden vijand, van felle muskieten, roode mieren en bloed zuigers. De schuilhoeken der negers waren zoo goed verborgen, dat men ze enkel bereiken kon wanneer overloopers het spoor wezen. Zoo men er niet spoedig in slaagde om den haas in zijn leger op te vatten, dan moest de tocht gemeenlijk worden opgegeven wegens ziekte, uitputting en gebrek aan mondkost.

Nepveu kende ten volle deze bezwaren, aan den negeroorlog verbonden; hij trachtte zijn doel, d. i. de pacificatie van het gewest, evenzeer door onderhandeling als door de wapenen te bereiken. En ook zijn voormalige patroon de gouverneur Mauricius, toonde met die moeilijkheden eener Surinaamsche guerilla bekend te zijn, toen hij den lezers van zijne Dichtlievende Uitspanningen daarvan eenig begrip trachtte te geven in de regels:

Misleide teekenaars! gij kent het land hier niet.

Hetgeen gij op de kaart als open velden ziet,

Zijn donkere wouden, digt met kreupelbosch bewassen.

Doorsneên met Zwampen en afgrijslijke moerassen.

Ziet, meet, hoe ' $t$ Land in diepte en breedte is uitgestrekt.

Zelfs als ge al blindlings, bij geluk, een Dorp ontdekt,

Dan is 't nog ver van hen te dooden of te vangen.

$\mathrm{Zij}$ slingren zich door bosch en ruigten als de slangen,

Daar gij niet volgen kunt. Het volk wordt krank en mort. 


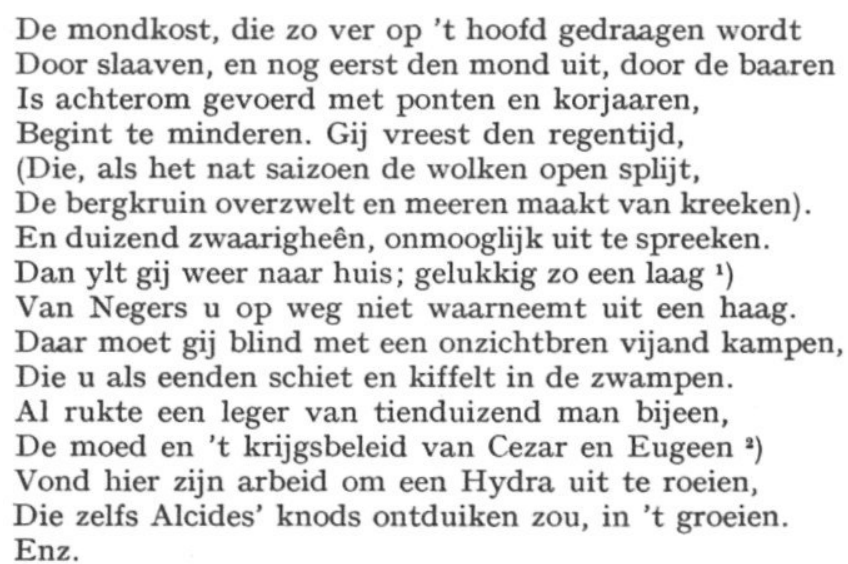

Een belangrijke maatregel werd door Nepveu genomen, toen hij den aanleg van den militairen Kordonweg doordreef. 't Was tegen de meening van Fourgeoud; gouverneur en kommandant waren het wederom oneens. En ook bij den Kolonialen Raad vond hij aanvankelijk heftigen tegenstand; zijn plan om het bebouwde gedeelte van de kolonie te omringen met eene linie van militaire posten werd door den Raad verworpen. Toch hield hij vol hij wist de machtiging der Staten voor zijne defensielinie te verkrijgen, en deze Kordonweg, in 1774 begonnen, was in 1778 voltooid. De weg liep van de joode Savane aan de Boven-Suriname tot aan zee als een stelsel van een groot aantal posten en verschansingen, onderling verband houdende. De bezettingstroepen werden verdeeld over de hoofd- en de mindere posten, terwijl om het kwartieruur gaans een piket de gemeenschap onderhield. De benden deserteurs werden aldus buiten het bewoonde gebied gehouden, en het Kordon vormde een krachtig bolwerk tegen de strooptochten der Boschnegers. Een dergelijk plan werd in later tijd op Java ten uitvoer gelegd, toen generaal de Kock in den vijfjarigen oorlog tegen den „hoofdmuiter” Dipo Negoro (die zichzelf, maar iets te vroeg, sultan van Java noemde) het veroverd terrein behield door het zg. benteng-systeem, nl. door de oprich-

1) Hinderlaag.

2) Prins Eugenius van Savoye. 
ting van militaire blokhuizen en schansen, tusschen welke de gemeenschap door een patrouille-dienst onderhouden werd, op soortgelijke wijze als Nepveu den dienst op zijn Kordonweg had ingericht.

De tropische hitte, de ontbering en vermoeienis veroorzaakten bij de koloniale troepen zooveel ziekten, dat Fourgeoud zich genoodzaakt zag de krijgsoperaties op te schorten. Ze werden hervat na aankomst van nieuwe versterkingen uit Nederland, en nadat nog twee kompagniën vrije negers waren aangeworven, aan welke een vaandel werd uitgereikt. Ten slotte gelukte het om de vijandelijke negerbenden onder hun opperhoofd Bonni over de oostelijke grensrivier, de Marowijne, te drijven, waarmee de veldtocht vooreerst als geëindigd kon worden beschouwd. De Boschnegers waren daarmee op Fransch grondgebied gekomen, en hoewel ze zich daar rustig hielden waren de autoriteiten van Fransch Guiana met deze nieuwe inwoners toch geenszins ingenomen. De zaak gaf aanleiding tot eenige moeilijkheden met het Nederlandsch bestuur; in verband daarmee kwam de Fransche intendant Malouet in 1777 te Paramaribo, waar hij met Nepveu en zijn raad herhaaldelijk besprekingen hield. De houding van den blanken meester tegenover den zwarten onderhoorige kwam toen mede ter sprake. Malouet achtte godsdienstig onderwijs der negers een voorname factor om eene pacificatie teweeg te brengen, en drong er op aan dat men geestelijken naar de Boschnegers zou zenden voor de evangelisatie. Hij stelde de vraag: „Waarom zouden onze Europeesche kolonisten alleen gebruyk maaken van de physique magt, daar zelfs de afschuwelijkste despooten nodig geoordeelt hebben de zedekunde daarby te voegen? Doch dit was den doove een sprookje verhaald, en gansch niet in den geest van de raadsleden te Paramaribo. $\mathrm{Na}$ vele discussiën in het Hof van Policie besloot men den Franschen zedemeester te antwoorden", dat het concept om die wegloopers door de religie te overreeden en in toom te houden, voorkomt te weesen van difficiele uitvoeringe en van verre uitzigte, vooral aangemerkt alhier de slaaven tot geen religie zijn overgebragt en dus te 
vreesen is dat, behalve de natuurlijke nijging tot haars gelijken, die men met de reeds bevreedigden ondervind, dit hen nog te meer daartoe sou nopen en aansetten."

Intusschen scheen Malouet, die van deze reis een belangrijk en uitvoerig verslag publiceerde in zijne „Collection de Mémoires sur la Guyane Française et Hollandaise", door zijne gesprekken met Nepveu over eene religieuse staatkunde, toch wel eenigen invloed op diens inzichten gehad te hebben. Aanvankelijk was de gouverneur geen voorstander van evangelisatie onder de negers; later kwam hij daarvan terug en vergunde aan de Moravische Broeders om het zendingswerk onder de „blinde heydenen" aan te vangen. Onder zijn bestuur, op $21 \mathrm{Juli}$ 1776, werd de eerste negerslaaf in Suriname door deze zendelingen gedoopt.

Sedert de vijandelijke Boschnegers over de Marowijne waren gejaagd en van het Nederlandsch gebied verdreven, werd de Kordonweg te zamen met de zwarte vrijkorpsen eene voldoende beveiliging voor de kolonie geacht. Derhalve keerde in 1778 kolonel Fourgeoud met zijn hulpkorps naar Nederland terug. 't Was eene niet geringe verademing voor den gouverneur, die aldus bevrijd werd van een bevelhebber, wiens gezag van het zijne onafhankelijk was geweest en die hem herhaaldelijk zijn licht betimmerd had. Trouwens, zulk eene gespannen verhouding tusschen den civielen en den militairen gezaghebber in de kolonie was geenszins zonder voorbeeld. Reeds de gouverneur der Westindische Comp. Joan Maurits van Nassau-Siegen had overhoop gelegen met den militairen kommandant Artichofski, en evenzoo Mauricius met Philippe Chambrier; de eerste een Pool, de tweede evenals Fourgeoud een $Z$ witser. Doch beide voorgangers waren er ingeslaagd zich dit blok van het been te schuiven en hun tegenstander de kolonie uit te werken; Nepveu daarentegen moest het dragen totdat het mandaat van dezen vreemdeling was afgeloopen. Beider afscheid was gewis niet zoo vriendschappelijk als de begroeting vijf jaren te voren geweest was, noch werd er zulk een festyn aangerecht als bij die gelegenheid. Stedman, die toen bij den 
feestmaaltijd in het gouverneurshuis mee had aangezeten, schreef er van:

„Men zag hier de uitgezogtste lekkernijen van Europa en Amerika in zilver opgedischt, de beste en verscheidenste wijnen wierden in overvloed geschonken, het nageregt bestond uit de kostlijkste vrugten en tot bediening was er een groot aantal Neger-Meisjens en jonge Mulattinnen, alle naar 's lands wijze naakt tot aan de lendenen, van daar nederwaarts in de fijnste indische chits gekleed en over het gantsche lijf met gouden kettingen, medaillons, halsbanden, armbanden en lieflijk riekende bloemen opgeschikt."

Ware er toen reeds een nieuwsblad in de kolonie geweest, het zou niet verzuimd hebben om van dit welkomst feest in den breede gewag te maken. Doch dit eerste persorgaan zag eerst in het volgend jaar het licht. Reeds onder het bestuur van Mauricius waren er plannen gevormd tot oprichting van eene drukkerij, en deze gouverneur had daarvoor eene afzonderlijke kas gevormd. Eerst in 1772 kwam de zaak tot stand, toen aan mr. Beeldsnijder Matroos, secretaris van het college van kleine zaken, voor den tijd van 25 jaren een "privilege van de drukperse" verleend werd. Twee jaren later bekwam hij eveneens het privilege voor de uitgave van een wekelijksche courant en een jaarlijksch Heerenboekje; op 10 Aug. 1774 zag het eerste nieuwsblad in de kolonie het licht onder den titel Wekelijksche Woensdagsche Surinaamsche Courant, in hoofde het wapen van de Societeit van Suriname dragende.

't Was eveneens onder het bestuur van Jan Nepveu, dat de muze der tooneelspeelkunst in het openbaar voor het voetlicht kwam. Evenals in Oostindië werd die kunst aanvankelijk slechts door amateurs beoefend; van beroeps-acteurs was te Paramaribo zoo min sprake als te Batavia. En beide koloniale tooneelen hadden het nadeel gemeen, dat er voor de vrouwenrollen geen vrouwen te krijgen waren. Men moest zich daarvoor behelpen met een baardeloos, of voor 't minst gladgeschoren jongmaatje. In Suriname lukte die metamorphose intusschen beter dan op Java, in zoover dat de sexie bedriegelijk werd nage- 
bootst, volgens getuigenis van den gouverneur zelf. In Nepveu's journaal vindt men aangeteekend, dat op 19 Juli 1773 werd opgevoerd het treurspel Sabina en Eponia, waarmee vermoedelijk bedoeld werd de Fransche tragedie van Rielier, Sabinus en Eponina, in de vertaling van Haverkamp. Het journaal bevatte daarover:

„Hedenavond is dit treurspel door eenige liefhebbers vertoond, alwaar beyde Haar WeldEd. Gestr. den heer Gouverneur en den heer Collonel Fourgeoud met diverse heeren en dames geïnviteerd zijn geweest; zeekere Schouten, van Amsterdam geboortig, alhier met een nigtje van de seer rijke swarte dame Nanette Samsom getrouwt, heeft daartoe een huys met decoratiën laten approprieeren, met de zinspreuk op 't voorgordijn: Pro Excolenda Eloquentia, wordende de meeste kosten van kleedingen enz. door denzelven gedraagen, gelijk hij ook zoo in 't Tragique als Comique wel speelt; 't voorneemen is om alle maanden een vertooning te geeven, 't welk dienen kan om de ingezeetenen bij deeze fatale omstandigheden van haaren miserable staat eenigzints te distraheeren. De Tragedie is zeer wel uitgevoerd, principalyk de moeyelijke rol van Eponia, die door een jongman genaamd Halloy admirabel uytgevoert is, synde nog 't wonderlijkste dat niemant, des onbewust, zou hebben kunnen merken dat het geen vrouw was; eenige jonge advocaten en practisyns vindt men onder de liefhebbers, dat haar teffens voor de Balie kan formeeren."

Uit dezen kern van een liefhebberij-tooneel groeide welhaast een ander van meer beteekenis; in 1775 werd een Hollandsche Schouwburg opgericht, waaraan enkele bezoldigde hoofdacteurs verbonden waren. En ook de moeilijkheid met de vrouwenrollen was men toen te boven; er traden bona fide actrices op in de stukken, die overigens zeldzaam genoeg ten tooneele werden gebracht; slechts zes of acht in een jaar tijds. Het verried de stemming in de kolonie tegenover de Joden, die toch tot de oudste volkplanters in Suriname behoorden, dat zij tot deze voorstellingen geen toegang hadden. $\mathrm{Zij}$ richtten toen een Joodsch tooneel op, dat een zekeren bloeitijd be- 
leefde en waar de opvoeringen zelfs talrijker waren dan in den schouwburg der Christenen.

Wel mocht Nepveu in zijn journaal gewagen van den „miserabelen staat” der ingezetenen, en van de kolonie in 't algemeen. Deze ging meer en meer onder schulden gebukt. Eerst de oprichting van de Vrijkorpsen, daarna aanleg en onderhoud van den Kordonweg zoomede de oorlogen tegen Boschnegers en Marrons hadden zware uitgaven gevorderd, die door leeningen bestreden moesten worden. Het gezamenlijk bedrag daarvan werd welhaast opgevoerd tot het cijfer van 60 millioen ${ }^{1}$ ). De gevolgen der $\mathrm{zg}$. negotiaties brachten het schip van staat nog meer aan den grond. In dien vorm, 'n soort van vennootschappen tot het uitleenen van geld op plantages, was, in 't bijzonder door Amsterdamsche handelshuizen, het kapitaal verstrekt noodig voor de uitbreiding der cultures en van den W. I. handel. De eerste van die negotiaties, eene uitgifte van 4 millioen als eerste hypotheek tegen 6 pct., was in 1753 opgericht door den Amsterdamschen bankier en burgemeester Willem Gideon Deutz. Het koloniaal bestuur verleende zijne medewerking bij het uitzetten dier gelden. Doch bij de schatting van de waarde der plantages, als basis voor de hypotheken, werd veel geknoeid, en de opgenomen gelden werden grootendeels niet voor uitbreiding van zaken aangewend, maar roekeloos verspild. Daarbij kwam het euvel van het absenteïsme, waardoor veel geld de kolonie uit ging; grondeigenaars, welke zich in Europeesche hoofdplaatsen vestigden en daar teerden van de opbrengst hunner plantages, die ze door zetbazen met den titel van administrateur lieten beheeren. De oorspronkelijke Surinaamsche planters verdwenen allengs, en tal van plantages, voor schuld verkocht, gingen voor een groot deel in Amsterdamsche handen over ${ }^{2}$ ).

In het jaar van Nepveu's definitieve aanstelling, 1770, en reeds een jaar te voren ontstond er een bubbel (Eng. bubble) in Westindische waarden, waarin een ieder zijn

1) Sypesteyn Beschrijv. v. Suriname. p. 40.

2) Over de Negotiatiên in voce Encyclop. v. W. I. 
geld wilde beleggen. Dit gaf aanleiding tot dolzinnige speculaties en tot een windhandel waaraan, mede ten gevolge van de crisis op de Amsterdamsche Beurs in 1773, onverwachts een einde kwam. De economische inzinking, welke het gevolg was van het barsten van den bubbel, veroorzaakte eene daling van de algemeene welvaart tot een ongekend peil. Nimmer zou de kolonie zich daarvan ten volle herstellen. Over de laatste jaren van Nepveu's bestuur wierpen deze gebeurtenissen een donkere schaduw, en de hachelijke economische toestand weerspiegelde zich in de aanteekeningen van zijn tot op het laatst bij gehouden journaal. De deerlijke achteruitgang van de kolonie smartte hem meer dan alle krakeelen met den kolonialen raad over de maatregelen om het zinkende schip te redden, en dan alle krakeelen met een naast hem geplaatsten machthebber, den kolonel Fourgeoud. Toch had hij in dien laatste niet zulk een geduchten en hardnekkigen tegenstander gevonden als Mauricius in Salomon Duplessis; den man, die als woordvoerder van eene vijandige planterspartij hem aanklaagde bij directeuren der Societeit van Suriname, en bewerkte dat hij teruggeroepen werd om zich te verantwoorden. Trouwens, Fourgeoud was reeds kort na zijn terugkeer in Nederland overleden, en zijn lijk was te 's Gravenhage met militaire honneurs ter aarde besteld.

Maar ook de dagen van Jan Nepveu waren nu geteld. $\mathrm{Na}$ een moeitevol, bijna tienjarig bestuur nam de dood hem dien ",regimentsstok” uit handen, waarmee ettelijke Oostindische landvoogden zich lieten afbeelden. Hij had bijtijds als gouverneur in ruste naar 't vaderland kunnen trekken, gelijk zijn voorganger Wigbold Crommelin gedaan had; hij stierf als soldaat op zijn post. Den $27 \mathrm{Fe}-$ bruari 1779 kwam hij, een zestiger, na eene langdurige ziekte te Paramaribo te overlijden. Zijn stoffelijk overschot werd op een paradebed voor de burgerij tentoongesteld en reeds den volgenden dag in het fort Zeelandia plechtig bijgezet ${ }^{\mathbf{1}}$ ).

1) Beschrijving van de lijkstaatsie in de Nieuwe Ned. Jaarboeken. April 1777 bl. 481. 
EEN WESTINDISCHE GOUVERNEUR UIT DE 18DE EEUW 527

Zijn portret werd in 1766, derhalve op een tijdstip tusschen zijn eerste en tweede optreden als gouverneur ad interim, geschilderd door den Dordtschen kunstenaar Tibout Regters. De gravure, door J. Houbraken naar dat portret genomen, stelt hem voor ten halven lijve, met een vleezig en baardeloos gelaat, het haar volgens de vaderlandsche mode van die dagen gepoederd en in boucles gefriseerd, de linkerhand gestoken in het lange zijden vest, waarover de fluweelen pandjas, afgezet met dubbel goudgalon en vergulde knoopen. Evenzoo de breede opslagen der mouwen, waaruit de kanten lubben te voorschijn komen.

Had zijn voormalige patroon, mr. Jan Jacob Mauricius in 1779 nog geleefd, hij zou de reeks zijner Dichtlievende Uitspanningen allicht vermeerderd hebben met een berymd bijschrift voor dit portret. En tevens zou hij daarin de nagedachtenis gehuldigd hebben van een kolonialen regent, dien zijne vijanden ter zake van zijne slimheid wel als een ,vos" plachten aan te duiden, maar die minder slimheid dan schranderheid betoonde in het besturen van de hem toevertrouwde kolonie, en die geen geringe plaats inneemt in de rij der Surinaamsche gouverneurs. 